\title{
Scientific Discovery in DeEp Social Space: Sociology without Borders
}

\author{
JOSEPH MichALSKI
}

\begin{abstract}
Globalization affords an excellent opportunity to develop a genuinely universal, scientific sociology. In recent decades, the politicization of the discipline has undermined the central mission of sociology: scientific discovery and explanation. The paper identifies several intellectual shifts that will facilitate expansion and communication in an emerging global village of sociological analysts: 1) breaking with classical sociology to build upon innovative theoretical ideas; 2) eliminating the ideological and normative focus that plagues much contemporary sociology; 3) moving beyond teleological approaches to scientific explanation; 4) embracing a distinctively "social" conceptualization of sociology's subject matter; and 5) eliminating nationalistic disciplinary boundaries and the attendant parochialism that obscures the search for universal principles of social behaviour. The final section of the paper emphasizes the internationalization of sociology, reorganized along epistemological lines. Those scholars whose research focuses on observable variations in social behaviour occupy an intellectual location quite distinct from those who place their politics at the centre of their social analyses, focus on the meanings that individuals attach to their experiences, or reject science altogether as a valid form of knowledge building. Rather than continue fruitless dialogues with those who have different objectives with their work, sociological analysts are invited to join a global village of scientists who examine the full range of cases that reflect purely social behaviour, drawing upon the dimensions of social space or networks of resource flows that are most relevant to their general explanations. Conceptualized this way, sociology becomes a global science no longer handicapped by individualistic theories or nationalistic political fervour. The net result is the development of a genuine "sociology without borders" aimed at realizing the discipline's fullest scientific potential.
\end{abstract}

Résumé. La mondialisation fournit un excellent prétexte au développement d'une sociologie véritablement universelle et scientifique. Durant les dernières décennies, la politisation de la sociologie a conduit au déclin de la mission centrale propre à cette discipline, celle de découverte scientifique et de recherche d'explications. Cet article identifie plusieurs changements intellectuels qui visent à faciliter l'expansion et la communication d'une telle science dans un 
village planétaire d'analystes sociologiques en émergence: 1) Rompre avec la sociologie classique afin de construire des théories sociologiques innovantes; 2) Éliminer la concentration idéologique et normative qui caractérise en grande partie les recherches sociologiques actuelles; 3) Dépasser les approches téléologiques et les remplacer par des explications scientifiques; 4) Conceptualiser la matière de la sociologie en termes clairement «sociaux» 5) Enfin, éliminer les frontières disciplinaires nationalistes et l'esprit de clocher qui leur est corollaire, car ils nuisent à la recherche de principes universels gouvernant le comportement social. La dernière section de l'article met l'emphase sur l'internationalisation d'une sociologie réorganisée selon des schèmes épistémologiques. Les spécialistes dont les recherches se concentrent sur des variations observables dans le comportement social ont une position intellectuelle bien distincte de ceux qui placent leurs opinions politiques au centre de leurs analyses sociales, se concentrent sur les significations que les individus attachent à leurs expériences ou encore nient à la science toute validité à fonder un savoir. Plutôt que de continuer un dialogue stérile avec ceux qui ont des objectifs différents pour leur travail, les sociologues sont invités à se joindre au village planétaire des scientifiques qui examinent l'ensemble des cas renvoyant à un comportement purement social. Il s'agit d'établir les dimensions de l'espace social ou les mécanismes des flux de ressources les plus pertinents pour fournir des explications générales. Ainsi conceptualisée, la sociologie n'est plus entravée par des théories individuelles ou des ferveurs politiques nationalistes et elle a le potentiel de devenir une science mondiale. Le résultat en sera le développement d'une véritable «sociologie sans frontières» apte à réaliser le potentiel scientifique maximum de la discipline.

\section{0.} stensibly founded upon a rich historical and comparative tradition, much sociology is too narrow in analytic scope, self-referential, and even parochial to contribute to grander debates about human social behaviour. The edges of the social universe, for many scholars, are defined by national borders and, in recent years, by identity politics that examine key issues in terms of group memberships and human rights (e.g., Blau and Moncada 2006). Sociologists, for the most part, have embraced diversity and inclusion as key markers of a "successful" sociology rather than the development of a cumulative knowledge base shared broadly across the discipline and aimed at explaining the social universe.

In an era of increasing globalization, however, the field has a historically distinct opportunity to transcend the parochial nature of much 20th century sociology, the predominance of survey research as the core methodological approach, and the various national sociological traditions that have evolved in recent decades. The current paper offers an alternative vision of scientific discovery in social space, or the development of a universalistic "sociology without borders" that social scientists can embrace everywhere there exists an interest in explaining human social behaviour. The proposals advanced here are intended to prod academic 
sociologists to reinvent and reinvigorate a discipline often dismissed as irrelevant or simply too ideological to contribute anything substantive to our understanding of the social world.

\section{Pluralism and Politicization}

Jonathan Turner (2006) argues in historical context that "American sociology" entered academia a century ago and evolved over the 20th century into a highly differentiated discipline without theoretical or epistemological coherence. Rather than developing an integrated body of knowledge, sociology has become arguably the most eclectic or, more pejoratively, the most chaotic of the social sciences. One could certainly make a strong case that a core foundation of knowledge still appears to be lacking. Even the introductory texts - despite the emphasis on the common sociological trilogy of structural-functionalism, conflict theory, and symbolic interactionism - vary considerably in their attention to particular theoretical perspectives and usually do not capture the field's latest developments (Best and Schweingruber 2003). What, then, do sociologists share in common? Attend a typical conference or even departmental meeting and the answer becomes readily apparent: not much. As Phillips (2001) has argued, a veritable "tower of Babel" continues to divide analysts into diverse subcultures and subfields within the discipline.

Sociology remains as divided, both as a multiple-paradigm science and through the varying commitments of its practitioners. ${ }^{1}$ The terrain can be confusing. Moreover, with an ever-expanding number of journals catering to the many genres of sociological analysis, one can hardly be expected to consume the full range of scholarly publications. Short (2006) has echoed a similar point recently in discussing the proliferation of journals merely within criminology. Yet many consider such epistemological diversity to be one of sociology's greatest strengths. The field captures a tremendous range of intellectual orientations: from critical social science, to various feminist analytic strategies, to interpretive sociologists, to positivists and postpositivists, and even the occasional postmodernist populating sociology departments (Camic and Joas 2004; Simpson 2005; cf. Collins 1990). I have long defended such pluralism out of respect for sociology's historical development first and

1. Abbott (2000:297) offers the following opinion: "Sociology's methods and theories are a grab bag (the polite phrase is 'multiple-paradigm science') when compared with the relative consistency of any of the other social sciences. Thus, whenever an island of the archipelago decides to become a separate principality, sociology has no obvious way of retaining dominion." 
foremost. In addition, the principle of academic freedom implies that scholars should be able to pursue whatever ideas might seem compelling, provided they can reasonably support their claims theoretically and methodologically among their peers. It may be time, however, to rethink the logic of such unabashed pluralism in an age where disciplinary incoherence reigns supreme.

More to the point: has sociology as a "science" failed? Best (2003:2) writes that "non-sociologists suspect that there isn't much to sociology, beyond a lot of unnecessarily complicated verbiage designed to give false authority to leftist politics." There are ample critics within the discipline too, though most spend their time attacking one or another of the epistemological frameworks of their adversaries (see Cole 2001; Horowitz 1993). What might advance the discipline or constitute "progress" depends on the ontological and epistemological stances of those who profess an answer. Regardless of the perspective, a widespread objective is discerning patterns in the conduct of human affairs - whether semiotic, behavioural, or structural in nature. The revelation of such patterns constitutes a distinct contribution beyond "common sense" or pure ideology.

Some sociologists infuse their descriptions with non-scientific observations; humanist, utopian, and moral claims abound in the interpretations and critiques of observed patterns. Some sociologists consider their activist agendas to be at the centre of their intellectual commitments, or simply deny the possibility that sociologists can be value-free or even value-neutral in their studies of social life (Arcaro 1996; Blau and Moncada 2007; Blackwell, Smith, and Sorenson 2003; see Tucker 1999). Under these circumstances, it is difficult to imagine that the majority would vigorously embrace or defend scientific sociology. As Horwitz (2002:644) contends, "many sociologists want their work to have political impact. They advocate the causes of downtrodden social groups or use general policy concerns and the desire to remedy social problems to direct their work." Indeed, the politicization of sociology extends even to our professional associations. Consider the case of the American Sociological Association (ASA).

In 2003, the members of "Sociologists and Political Scientists Without Borders" circulated a resolution outlining their concerns about the United States' international policy, with a particular focus on the intervention in Iraq. The resolution concludes as follows: "Hence, the American Sociological Association calls for an immediate end to the war against Iraq." Apart from $22 \%$ who did not vote, the majority (65.8\%) of the ASA membership voted in favour of the resolution, with $34.2 \%$ opposed. Interestingly, a similar resolution circulated in 1968, on the 
Vietnam War (i.e., for an end to the bombing and immediate withdrawal of US troops), did not pass. According to the American Sociological Association (2003a) website,

While a simultaneous poll of opinions indicated that a majority of the Association's voting members favored the resolution's policy position, a majority was not willing, at that time, to view a policy position on such an issue to be consistent with the role of a scientific and professional society, thus defeating the resolution.

The difference in membership reactions to these resolutions reflects a cultural shift toward value engagement and activism, or the further politicization of the profession. Those who opposed the 2003 resolution outlined several concerns and potential violations of the ASA's Code of Ethics, which specifies that sociologists must "provide service only within the boundaries of their competence, based on their education, training, supervised experience, or appropriate professional experience" and "rely on scientifically and professionally derived knowledge." The ASA should refrain from policy positions in the absence of a "solid foundation of sociological knowledge as well as widespread agreement on its policy implications" (American Sociological Association 2003b:2). Whatever the merits of the arguments advanced by those who supported or opposed the resolution, the net result proved yet again the divisiveness of politics and ethical systems designed to advance particular dogmas and ideologies. We should not be surprised that disagreements abound where sociologists advocate for particular political positions rather than a shared ethic aimed at uncovering new knowledge. As the theoretical physicist Lee Smolin (2006:302) observed recently: "When people join a scientific community, they give up certain childish but universal desires: the need to feel that they are right all the time or the belief that they are in possession of the absolute truth."

Physicists are by no means alone in this orientation toward science. Many sociologists dream of achieving the grand objective of a truly explanatory science of social life (Black 2000a; Cooney 2002; J. Turner 2003). Tucker (1999:402) reminds us that not all sociologists wish to be policy advisers or world savers: "Some of us are truly excited about the scientific enterprise. We conduct research and develop theory hoping to contribute to a more advanced social science." Where and when that happens, one might even anticipate the creation of a new category for the Nobel prize that will be distinguished from the economics prize. In the "global village" of social scientists in the 21 st century, surely one can imagine a sociology that embraces the development of universal standards of excellence to recognize achievement in the most "social" of the 
social sciences. That is sociology's best hope for intellectual survival: to unleash the creative, analytic capacities of a community of seekers, committed to discovery and explanation. Otherwise, the discipline will merely continue to cast about aimlessly from country to country, and from department to department, as another effete "ology" withering on the vine of dogmatism.

The current paper outlines an alternative future for sociology, one that enhances our prospects for survival in a fertile crescent of ideas uniting analysts globally: the development of a genuinely universal, scientific sociology. Globalization offers a unique opportunity to develop an exciting, groundbreaking science of social life. The heart of the analysis identifies key intellectual shifts that will facilitate expansion and communication in an emerging global village of sociological analysts. The final section of the paper emphasizes the internationalization of sociology, based on an epistemological realignment and reorganization. The net result is the development of a "sociology without borders" aimed at realizing sociology's fullest scientific potential.

\section{Generating Global Excitement for the Social Universe}

While much scientific inquiry may be mundane or repetitious, sociologists would do well to bring the same interest and excitement to the discipline that natural scientists often seem to have in their fields. For example, in 2004, evidence for the detection of "dark matter" generated international headlines, as the global phalanx of physicists weighed in with alternative views and theoretical interpretations. In The Toronto Star, an article that featured a University of Toronto astronomer began: "Roberto Abraham is a detective whose mystery has no end: it's the mystery of the universe itself." I have never seen any sociological media articles that begin with a comparable catchphrase, i.e., that "such-and-such is a sociological detective whose mystery has no end: it's the mystery of the social universe itself."

We seem to be forever chiding ourselves, lamenting our collective lack of respect as a discipline, sometimes doubtful or even hostile toward the effort to be scientific in the study of social world (see Best 2003; Cole 2001). In fact, some scholars believe that there is no need to gather any more "data" or "information" about the social world, for what more can be learned by such "mindless empiricism?" Back to Dr. Abraham:

A year ago, when the award-winning University of Toronto astronomer scanned the outer reaches of the universe on a powerful Hawaiian-based telescope, he was expecting to confirm what most scientists took for grant- 
ed: that big, mature galaxies in that ancient area of 'deep space' were virtually non-existent. Instead, Abraham and his team made a stunning discovery - that large elliptical galaxies existed much earlier than anyone suspected.... 'No one was more surprised than I was.'

The article later quoted Abraham as saying, "The universe has certain key parameters that are only just being determined now. For an astronomer, it's an awesome time to be alive."

Can the same be said of sociologists? Absolutely! Those who are committed to scientific discovery and investigation in the social sciences finally have many of the tools and resources necessary to succeed in ways that scholars working in the field only a half century ago could not have imagined. The expansion and democratization of computers, as well as innovations in communication technologies, allow for transnational and almost instantaneous sharing of information. The longitudinal, historical, and comparative datasets at our disposal have reached unprecedented levels in terms of both quality and quantity. Although funding will always be a contentious issue, a great many sociologists can proceed with their work unencumbered by the need to have multimillion dollar instruments at their disposal and can conduct much of the necessary work to explore the depths of the social universe virtually "on their own."

To study the social universe on one's own does not mean that sociologists should create unique meaning systems grounded in their personal experiences and interpretations, or follow the postmodernist mantra that "objective truth" does not exist and no theoretical formulations can be judged to be more "correct" or "valid" than others (Lyotard 1992; Sarup 1993; see Spiro 1996). Such perspectives focus on particularistic interpretations of the social world, forever leaving the observers isolated on their own islands of intellectual reality, accompanied perhaps by a smattering of disenchanted followers. Studying the social universe ideally invites dialogue and discourse with the shared objective of unlocking its deepest mysteries and explaining these in a scientific language shared by peoples across cultures and in every corner of the globe. This, however, requires a commitment to move beyond several dominant influences that have shaped generations of sociological analysts. The crucial intellectual shifts required to ensure the development, expansion, and communication of a distinctly global sociology are discussed in the next segment of the paper. 


\section{InTELLECtual ShifTs toward a GLOBal Sociology}

\section{Shift 1: Breaking with Classical Traditions}

Black (2000a; 2000b) argues that the intellectual malaise plaguing contemporary sociology can be partly attributed to the fact that the discipline has never really had a revolutionary break from its classical tradition. For example, sociology programs everywhere routinely require at least one course on "classical sociology," often in their graduate programs as well. Some sociologists even argue that classical sociology still offers exemplars for the most compelling sociological work ever produced (Alexander 1987; Camic 1998; S. Turner 1996). If the field continues to be inspired by the classics, then to what extent can one argue that sociology has evolved theoretically over the past century? One can readily observe that the dominant paradigms of the discipline today have their roots in the work of Durkheim, Marx, Simmel, and Weber (among others). Some who work within these analytic traditions continue to cite the original works with reverence. It would be interesting to compare the extent to which doctoral students in sociology make obligatory references to the classical works in their field versus the citation practices of doctoral students in the "natural sciences." Black's (2000b:705) criticisms are worth noting:

Classical sociology was new and exciting a century ago, but now it is a dead end. It tells the same story over and over: The social environment has this or that impact on how people pursue their goals. Moreover, whatever teleological, psychological, and individualistic sociology may have accomplished in the past, sociologists have always been unable to explain the spectacular diversity of social life across the world and across history in the countless societies that have existed.... And where is the sociological theory applicable to every conceivable instance of anything across the social universe, past, present, and future? Where is the theory unimaginable a century or half-century ago? Because it follows the classical tradition, modern sociology is unable to discover anything radically new. Everything is completely normal. Nothing amazes anyone. The field is frozen in scientific time.

While many sociologists would take issue with the claim that nothing new has been discovered in the last several decades, Black's critique has considerable resonance. Even among the research-oriented sociologists (as opposed to those who mainly "teach"), how many rush to devour the latest articles published in leading journals or regularly find that these are brimming with insights and revelations previously unimagined? How often are the most recent discoveries from the discipline 
featured in the news or general science magazines? Not long ago, sociology found a place in the Toronto Star - a rare occurrence indeed. Yet what was the primary reference or revolutionary theory being presented? Durkheim's Suicide. The article cited Durkheim's work as continuing to influence social scientists today, some of whom have drawn upon his theory to explain why "terrorists" have had a tendency in recent years to engage in "suicide bombings." One should be reminded that Durkheim's Suicide, as with most "sociological" explanations, rests primarily upon a psychological interpretation of individual behaviour focusing on motivations or goal-seeking behaviour. Although fascinating to observe that classical sociology can be invoked to discuss contemporary issues, we must ask: can sociology offer something more? Can sociology be "postideological," "post-teleological," and even "post-national"?

\section{Shift 2: Discarding Ideology to the Trash-bin of Sociological History}

Unfortunately, Black (2000b) correctly describes an even bleaker state of affairs in contemporary sociology: many sociologists today are even less scientific than their classical counterparts. Describing the situation as "scientific devolution," Black notes that many sociologists reject the notion of a value-neutral or otherwise scientific sociology. His contention is supported by the earlier example of contemporary sociologists endorsing political engagement over the scientific mission of the discipline in the United States. In Canada, more than half of a random sample of sociologists surveyed purport to practice and teach out of a "critical" sociological tradition and do not believe in "value neutrality" (Michalski 2005; see McLaughlin 2005). Even more radically, some pursue explicitly ideological agendas in the name of sociology, abandoning any hope or desire for scientific discovery. For example, one recent interviewee for a sociology position was asked about the " "why' question of crime ... are you searching for an explanation?" The candidate responded as follows: "Well, I mean from a Marxist perspective the why has already been answered, all right? So for me there really isn't a need to try to search for an explanation for behaviour." One might just as readily substitute "Christian fundamentalist" or "radical Islamic" for "Marxist" and the ideological nature of the argument would be equally evident. Once again, can sociology offer something more? Can sociology be "postideological?" Yes. Here are three examples:

1. In a particular society, law varies directly with relational distance (Black 1976:40-46).

2. The relationship between violence and third-party status superiority is U-curved (Cooney 1998:38-44). 
3. Welfare varies in a direction toward less social integration (Michalski 2003:349).

The first proposition derives from Black's more general theory of law, in which he argues that governmental social control (law) increases as the relational distance between disputants becomes greater. In empirical terms, the proposition helps order a broad range of facts, including the considerable evidence that intimates, for example, are far less likely to pursue their grievances through the law than those who are more socially distant from one another. The proposition suggests nothing about the "desirability" of law or the ideological bases for constructing legal systems or their implementation. Instead, the proposition merely orders the broadest known range of facts about one sociological dimension (relational distance) that affects the behaviour of law.

The second proposition derives from Cooney's (1998) work on how third parties tend to shape violence. The proposition suggests that violence is more commonplace between disputants where available third parties tend either to have much higher or much lower status than the principals involved. Cooney (1998) explains that third parties with much higher status than disputants can be much more coercive, punitive, and even repressive with their interventions. Third parties who share a similar status to the disputants or who have slightly higher status will tend to intervene more as mediators or engage in peace-making behaviour. Finally, since disputants usually look toward those of higher status to help resolve their differences, third parties with lower status will tend to be ignored (Baumgartner 1988). This results in fewer peaceful alternatives to resolve the conflict and hence, all else constant, violence will tend to be more commonplace among low-status individuals. Once more, such formulations not only ignore ideology altogether, but have the added benefit that they can be readily tested.

Finally, I avoid implicating ideology with the formulation that welfare varies in a direction toward less social integration (Michalski 2003). By welfare, I mean unilateral transfers of financial resources. Such transfers predictably flow directly from those who are more integrated in social life toward those who are less integrated. Even among those who are poor and marginal in a societal context, the theory predicts that welfare will flow toward even greater marginality.

All three propositions identify behavioural variations in social phenomena, specify factors that purportedly "cause" or at least contribute to observable variations, and yet remain entirely silent on questions of ideology or the relative value of such relationships. Values clearly enter into the analyst's decision to pursue certain lines of inquiry rather than others and may infuse other aspects of the research process. The 
theoretical predictions, however, are post-ideological. Regardless of one's politics or ideological orientation, the propositions can be tested and verified (or falsified) with empirical evidence. Whether or not anyone prefers that such a world exists, or might work to change such patterns (if observed) lies beyond the scope of science. While one might be inspired to use the scientific knowledge for political or ideological purposes, that reality again does not discredit the post-ideological nature of such rigorous and testable scientific formulations (see Black 1989). Sociologists everywhere, in principle, should be able to adduce evidence relevant to the above propositions, or engage in the broader conversation about what other factors may influence the behaviour of law, violence, or welfare. Scientific sociology invites and thrives on such theoretically imaginative and yet empirically grounded discourses.

\section{Shift 3: Beyond Teleological Paradigms}

Apart from the confusion between ideological and scientific statements, sociology has been plagued since its inception with an existential problem regarding the "why" of human behaviour: to what ends are human social behaviours directed? Virtually every major sociological paradigm poses an answer to that question by addressing human behaviour teleologically, i.e., as a means to an end. These theoretical ventures typically trace their explanatory logic back to the psychology of the individual, casting about to discover some underlying motivation, rationale, or meaning that may underlie the behaviour in question (e.g., Coleman 1990). The ends might be to meet personal needs, to construct a meaning system that helps individuals understand their reality, to benefit a dominant group in subordinating other groups, or to uphold the capitalist system (among countless other possibilities). In this sense, then, Black (1995; 2000b) has argued that teleology constitutes the "super-paradigm" of sociology that guides virtually every train of theoretical thought.

In reviewing most sociological research, the extant social scientific explanations tend to be highly teleological: functionalists claim that existing structures meet the functional requirements and needs of the system; conflict theorists explain that social life consists of individuals and groups with competing interests who pursue their goals in competition with one another; social exchange theorists take their cue from economics to defend a rational-choice model of human behaviour in suggesting that individuals are pleasure-seeking, pain-avoiding, utility maximizers; and feminists argue that patriarchal systems are constructed and legitimized to protect men's interests while simultaneously disempowering, oppressing, and controlling women. 
The problem with this reasoning has always been the quasi-religious character of the theoretical formulations: how does one know that these are the core objectives or purposes underlying human social behaviour? Others seem to "know" what lies in "the sealed chamber that is the human mind" (Cooney 2002:660). The rational choice theorist confidently asserts, "well, Mother Teresa is (or was) the most selfish person in the world, because she's just trying to fulfill her own needs by serving the poor in Calcutta." Her service to others reduces to a utility function. As Etzioni (1988:25) explains, "When a person acts altruistically, this is explained by the suggestion that the pleasure of the person who benefits from this act has become a source of [the] doer's pleasure, part of his or her utility." Such an all-encompassing concept, whereby human actions are motivated by utility, cannot be falsified and thus loses its explanatory value. Hence the possibility of sociological explanation without such assumptions about goals, values, needs, functions, interests, intentions, motives, purposes, or preferences is rather intriguing. Without being certain of my own internal states or motives, how can I be so presumptuous to somehow "know" the internal motivations, interests, or needs of others?

A global sociology, therefore, would benefit a great deal from the elimination of teleology as an organizing principle. One has to be prepared to embrace a sociology that makes no assumptions either about the ends of social life, or that human beings behave as they do to satisfy particular needs or for any specific purposes (Black 1995; 2000a; 2000b). Just as we cannot "know" to what ends the physical universe continues to unfold or its ultimate fate, we cannot know to what ends the social universe may be directed. These are questions better suited to philosophers and religious practitioners. Yet sociologists regularly engage in such discussions, seemingly unable to restrain themselves from speculating on the ends and even the morality of human behaviour.

By way of comparison, we can observe physical phenomena such as the strength of gravity decreasing with the distance between two objects (with mass) proportionally to their distance squared - which we commonly refer to as the "inverse square law." The use of the scientific method and theoretical reasoning resulted in the "discovery" of this "law" that helps organize a vast array of empirical evidence. In general, most observers will be satisfied to have learned about the law and the underlying principle of gravitational attraction without further asking "why." The covering law model approach in the natural sciences permits the statement of the relevant conditions from which the behavioural outcomes may be deduced and even predicted. 
Interestingly, the propositional parallel in sociology that, ceteris paribus, "law (governmental social control) varies directly with relational distance" does a remarkable job of ordering the known facts that link these two phenomena. In fact, such a "law" of law has yielded some of the most consistent predictions about the behaviour of law known to social scientists (Black 1976; 1995). Yet the deductive reasoning model approach to scientific explanation does not satisfy traditionalists who believe there must be something more to explain the behavioural regularity. Is it really necessary to interrogate the proposition further to ask "why" that should be, or to speculate as "to what ultimate ends" such behaviours may be directed? What more can be gained? The principle powerfully organizes the evidence and thus explains one specific form of social behaviour, at least within certain parameters. If anyone can identify a more powerful and yet more parsimonious relationship, then who would not welcome such new knowledge?

\section{Shift 4: Embracing the Social}

One of the most remarkable aspects of sociology's development has been the reluctance of many sociologists to embrace the "social" as the core, organizing feature of the discipline. The social disappears altogether from the analysis, as individuals usually constitute the key unit of analysis in sociological investigations. Survey research methods, our disciplinary bread and butter, can be faulted here to some extent. The use of surveys to gather information about individuals, including their alleged "social" characteristics (e.g., gender, age, race/ethnicity, family/ household size, education, income), can yield tremendous amounts of information about the members of a population efficiently. Scientific sampling procedures and rigorous methodological rules help to ensure a high probability that these characteristics can be summed across elements to accurately reflect population parameters. Yet the link with anything social remains at best indirect: what has really been measured beyond various aspects of these individuals' lives, their backgrounds, and their attitudes and beliefs? Most survey research, therefore, reveals almost nothing truly social about the individuals involved, if by social one means the patterned connections or relationships between or among constituent elements (Michalski 2004; see Snow 1999).

Indeed, one could argue that much of sociology, especially in the latter decades of the 20th century, has been dominated by "individualism" rather than anything distinctly "social" in nature. Mayhew (1980:339) offered one of the most salient critiques of individualism as our disciplinary bane nearly three decades ago, arguing that 
... most American sociologists adopt the individualist perspective in that the individual is their unit of analysis and so-called 'human behavior' (in both its subjective and objective aspects) is the individual level phenomena they seek to explain and interpret.

While some theoretical work has been able to transcend such an individualist focus, the cul-de-sac or "blind alley" of individualism arguably has stymied the advance of a truly unified sociology of social life.

Hence the focus on the social or clearly relational aspects of the human condition would be revolutionary should the discipline embrace that logic in a more exclusive and even territorial way. Yet most sociologists have not made the "clean break" necessary to help fertilize the sociological imagination. According to Mayhew (1980:364), "There is one sociology called structuralism and one psychology called individualism. Because it has been dominated by the psychology called individualism, American sociology ground to a stop the day it was born." In the past three decades, the situation has hardly changed. Many network analysts have moved toward a post-individualist focus, as have some analysts who work in historical-comparative sociology. An entire school of sociology known as "Blackian sociology" or "pure sociology" embraces the subject matter entirely at the level of the "social." Other exceptions can be identified, but these remain minority voices within the discipline.

The focus on the social or relational aspects of the human condition by definition means transcending individualism. No longer would we have to search from among the myriad individual reasons or motivations to examine the outcomes of interest, at least by studying the purely social. The study of the relational is an intellectual shift that can generate the centripetal forces necessary to establishing a disciplinary core. Just as important, such a focus allows practitioners from a variety of different perspectives within the discipline to engage the subject matter in interesting and diverse ways: from the more generative (e.g., Smith-Lovin 2000), to the network processing with resource flows (e.g., Amato 1995; Warde and Tampubolen 2002), to the study of similar cases that share a confluence of common precursors (e.g., Miethe and Regoeczi 2004), or perhaps a common social geometry (e.g. Black, 2004). The search for behavioural regularities at the level of the social invites analysts from across the globe to feast at a common table of intellectual inquiry.

\section{Shift 5: Beyond Nationalisms}

Finally, a genuinely scientific sociology eliminates the logic and relevance of nationalistic disciplinary boundaries. The reality that particular countries have distinct intellectual traditions and identifiable strengths 
with respect to historical developments within the field cannot be disputed (Fuller 2000; Halsey 2004; Hiller 2001; Lipset 2001; McLaughlin 2004; Ogmundson 2002). But why should the important substantive issues and theoretical breakthroughs in the human sciences be linked to or defined in terms of nationalisms or particular institutional contexts? The scientific questions, theoretical propositions, and empirical testing relating to "dark matter," for example, do not require that we identify whether the analyst approaches these issues from a Russian, French, Indian, or Canadian perspective.

Similarly, why should the question "What explains variations in the behaviour of law" be linked to analysts working only within specific countries? Framed this way, the question can be addressed by sociologists anywhere in the world. The fact that Black (1976) already has identified many of the key theoretical propositions should not dissuade others from continuing to refine the theory and certainly does not mean that empirical testing should cease. To the contrary: that work should inspire the best and the brightest interested in the sociology of law to continue developing testable theory and refining our understanding of social behaviour. Every new discovery enlightens us by explicating further the dynamics underlying the behaviour of law, if only by demonstrating that certain paths are dead ends. In either case, knowledge increases.

Critics of this approach, of course, have dissented with arguments that range from the philosophical to the practical. Some analysts debate the ethical aspects of social research, infusing their discussions of sociology's research questions with the political aspects of social inquiry: the "knowledge for what or for whom?" perspective (Gouldner 1970; Lee 1976; Lynd 1939; Mills 1959). Other critics doubt the possibility of developing any universal set of principles that transcend language and cultural history to explain human social behaviour (e.g., MorrisSuzuki 2000). Still others offer institutional or analytic critiques, such as McLaughlin (2005:31), who suggests the following about sociology in Canada:

We do not have the university or societal resources, the granting agencies and elite foundations or the political will to establish a fully scientific sociology, unconnected to applied programs, public intellectual life, the state or student demand for undergraduate education. (emphasis added)

If true, then sociology will continue to fail as a science and many sociological practitioners in Canada and elsewhere will inevitably continue to dash McLaughlin's (2005:31-32) hopes for the disciplinary future, i.e., "that political criteria does not come into hiring decisions ... and that scholarly excellence anchors the leadership of the discipline and our 
departments." The crisis that McLaughlin fears, though, has already arrived; anecdotal evidence suggests that some Canadian sociology departments are driven almost dogmatically by political criteria in their hiring practices. ${ }^{2}$ Canadian sociology exists already as equal parts "shill" in the service of the welfare state, "grab bag" lacking in intellectual coherence and scholarly status, and "service department" providing employment training for left-wing activists and others with a vested interest in giving voice to the marginalized or participating in various forms of social activism. Knowledge for what indeed!

\section{SCientific Contributions}

Perhaps part of our disciplinary stumbling stems from the many critiques of "science" (and a narrowly conceived "positivism") over the past few decades, which have opened the floodgates to the competing truth claims that abound. Some analysts will doubt the existence of a world "out there" and continue their metatheoretical attacks on science until the end of their days. The fact that they use computers to develop these critiques, which involve transfers of energy that are well understood with scientific principles (and publish them in books or on the internet) will in no way dissuade them from their mission to deconstruct science. For everyone else, though, it is important to understand that the scientific enterprise offers a great deal of common communicative ground - arguably the most common ground - as a truth system widely shared across a great many societies. Science can have a remarkably unifying impact, if conceived as the interplay between theoretical formulations and empirical investigation. Two decades ago, Collins (1986:1345) argued that

the essence of science is precisely theory ... as a generalized and coherent body of ideas, which explain the range of variations in the empirical world in terms of general principles. Even more centrally, it is explicitly

2. A detailed analysis lies beyond the scope of the current paper, but an example helps illustrate the point. At one university a few years ago, I could not understand why I had not been short-listed since I had: a) more Sociological Abstracts citations than the entire department combined for the year in which I had been applying; and b) received consecutive nominations for outstanding teaching awards in exactly the areas advertised. Neither the Dean nor the Chair ever explained why I had been omitted from the short-list of candidates beyond "each member chooses as s/he wishes." The department's radical leftist orientation included members regularly posting anti-American literature in the hallways. Neither condition boded well for an "American positivist" seeking employment at such an institution. In fact, several members grilled another colleague on contract about her politics at lunch one day and were dismayed to learn that she was not a radical leftist, even though she was a woman of colour. She was not short-listed either. 
cumulative and integrating. General principles must be true across the widest range of application; this means that a real science connects specialties together.

Sociology can certainly be a "real science."

Perhaps part of the confusion is what constitutes discovery or scientific advances in the social sciences. The importance of establishing clear criteria cannot be overstated, for a great many sociological practitioners no longer subscribe to certain core principles of scientific analysis. Black (1995) proposes several key criteria in his epistemological defence of "pure sociology," which apply to science everywhere (as a colleague from psychology noted in reviewing this paper). The theoretical contributions of scientific sociology should be judged by the following standards: testability, generality, simplicity, validity, and originality. The best of our formulations should be subject to falsification, explain the full range of phenomena under investigation in the most parsimonious fashion, order known (and predict unknown) facts, and demonstrate innovativeness and logical integration (see Collins 1986). Any sociology that claims to be scientific should be judged by these criteria. On these bases, then, increases in sociological knowledge ultimately transcend national boundaries. The theoretical propositions generated should apply to and be testable everywhere there exist comparable cases of social behaviour, forever subject to the empirical challenges of new evidence and thus provisional in nature. Extant theory can always be revised where patterns do not hold and, ideally, the sociological detective will be able to explain why the theory does not hold in all cases and should be modified accordingly.

Wherever law or "governmental social control" exists, for example, it can be studied sociologically and different propositions deduced from Blackian theory can be tested. The most scientific sociology, therefore, requires that sociologists abandon the parochialism of studying simply their "own" people living in their "own" countries and specific historical periods. In fact, Black (2002a) argues that sociologists are often too close in social distance to what they study to be truly scientific. As a result, sociologists rarely "discover" anything new about their already close subjects and usually fail to establish more general explanatory propositions. ${ }^{3}$ The most scientific sociology requires an historical and

3. The sociologist who studies oneself reflexively occupies a position in social space, by definition, closest to the subject. One can predict that such self-studies rarely, if ever, yield theoretical insights that might contribute to an explanatory social science. In fact, the objective of those who engage in "thick description" appears to be much more humanistic, semiotic, teleological, and individualistic in nature - the antithesis of the goals to which scientific sociology aspires. 
comparative focus, for much of the evidence needed to test propositions such as "law varies directly with relational distance" already exists, but in places where sociologists rarely look: in the volumes that historians have written, the ethnographies that anthropologists have compiled, and wherever solid data have been gathered to describe instances of the behaviour of law across time and space.

The most ambitious of those committed to scientific sociology attempt to explain all instances of distinct classes of social behaviour across cultures and across history (Black 1979; 1995; 2000a; 2000b). With the existing communication technologies and rich sources of comparative data available (e.g., the Human Relations Area Files), sociologists can broaden their horizons to accomplish more than even the most diligent Weberian (or Weber himself?) from the past century. Furthermore, while some have expressed concerns about the electronic archive known as the Internet and the interactive transformations that these may produce (Featherstone 2000), the capacity to store, search, communicate, and analyze cultural information has never been greater.

Sociology as a science thus requires a commitment to transcending nationalism and, in a sense, even becoming "post-global" to think about the social universe as having invariant properties across space and time. The focus on particular national contexts provides ample grist for the historical mill, but will not likely yield the necessary output to sustain a universalistic approach that engages a core group of like-minded sociological analysts around the world. Scientific sociology highlights the importance of discovering and explaining historical and cross-cultural patterns of social behaviour, which might be hypothesized, for instance, to be the byproduct of the social geometry in which such behaviours occur (Black 2002b). At the very least, if the social universe changes, then we should be able to uncover why patterns of social life change or why particular "laws" do not remain invariant. Finally, scientific sociology requires the embrace of a new epistemology and the development of more innovative methodologies to gather evidence and to test propositions.

\section{Sociology without Borders: Some Practical Suggestions}

No shortage exists of sociologists who have formulated mission statements or otherwise constructed alternative visions for the future of sociological analysis. As with religious fissures or any "truth system," intellectual divisions will continue to inspire strong reactions: from those who endorse enthusiastically particular schools of thought to those who are horrified equally by those traditions. As yet we have no ultimate 
means to judge the veracity of these alternative visions, save perhaps for our commitments to particular ontological and epistemological assumptions. Sociology, as a discipline, has responded to this conundrum by expanding the disciplinary boundaries over the past several decades to be ever more inclusive.

A great many sociologists will continue to endorse intellectual pluralism as healthy for a multiparadigm discipline. As stated at the outset, I have long championed such a position myself. Yet in trying to defend a plurality of perspectives or different types of sociology, invariably I encounter the sentiment that the pursuit of a purely scientific sociology is not only impossible but immoral. While defending the call for equal recognition of different approaches, to be represented within and across sociology departments, the critical theorists typically dismissed the call in person, in their classroom lectures, and in print - often to the point of attempting to exclude "positivists" altogether from their departments. Thus I have always been at a philosophical disadvantage in advocating sociological pluralism in the face of the hegemonic aspirations of many critical theorists. ${ }^{4}$

It is not enough for the radicals and critical theorists in our discipline that one should proclaim one's leftist leanings and sympathies; one must simultaneously endorse the view that sociologists should vent their morality. For example, Jonathan Turner (2005) repeatedly states that he shares left-leaning ideological commitments, but then argues that we lose credibility once we start moralizing or if the public perceives that our knowledge has been corrupted by political ideology. In response, Burawoy (2005:154) offers a scathing critique of Turner and the purely scientific approach of the "Strong Program in Professional Sociology," claiming once again that "social science without values is impossible." The current paper, though, has already provided several examples that refute such a naïve statement. Baumgartner (2002:646) offers an even more succinct and powerful argument regarding the possibility and promise of value-free sociology in Black's (1976) work:

Black's remarkable success in ordering and explaining a large number of findings without ever confusing facts and values, along with his total absence of moralizing or policy advocacy in his work, serves as dramatic proof that value-free sociology is indeed possible and capable of considerable achievement in its own terms. Black's work thus refutes the claim that sociology cannot produce value-free analysis.

4. Jonathan Turner (2005:28) accurately summarizes the point in explaining that the raison d'être for critical sociology consists of questioning "the moral vision and foundational assumptions of all other sociologies, but particularly professional sociology (committed to science)." 
Burawoy's (2005:154) critique also claims that Turner (2005) fails to present evidence of the "attack dogmatism" of critical theorists and the notion that there are "hapless graduate students misled by unnamed and irresponsible faculty." Yes, ideally one should provide evidence for such claims, though the ability to document the full range of such attacks or their prominence within the discipline would be a monumental challenge. For those who are interested in some related data, though, a recent self-report survey determined that fully two-thirds of university-based sociologists in Canada reported subscribing to a critical and/or feminist epistemological perspective (Michalski 2005). Only one in five academic sociologists described themselves as "positivists" or "post-positivists." Such evidence suggests that scientific sociologists are at the margins of the discipline, at least within Canada. Turner's (2005:36) suspicion that "it is science that is being beaten out of students by their fellow students and by activist faculty members" is at least plausible.

The quibbling between scientific sociology and critical sociology will continue indefinitely. Perhaps the time has come at last to abandon any hope of disciplinary reconciliation. It is hard to change, more difficult still to abandon what we covet, and virtually impossible to subscribe to radically new alternatives. I do not expect most readers to endorse what I am about to propose, for the resistance will surely be strong to any calls to dismantle or realign the dominant intellectual and departmental frameworks. Yet that is what we must do if we are to fully realize the scientific promise of sociology.

\section{Suggestion \#1: Re-establish the Core}

Sociology requires a disciplinary core. Lacking a consensus on a substantive core, there will continue to be rival worldviews and an incoherence that stifles any realistic chance at knowledge advancement. In fact, some of those reading the current piece will almost certainly take exception to this central aim, as other disciplinary objectives will seem more urgent, more relevant, or simply more interesting. How can we ever agree on the core? As suggested previously, the core that derives logically or perhaps etymologically from the subject defined as "sociology" would be the "social," i.e., the science of social life or the "behaviour of social life." 5

5. The "social" will require much more fleshing out than current space limitations will permit (see, for example, Turner, 2006). For the moment, though, the social refers to interpersonal (interorganismal?) interactions between or among constituent elements within an identifiable time and place. Social life, then, has a reality sui generis from biological or psychological life - no less "real" or significant - but with far fewer scientists committed to investigating such life. 
Narrowing the subject matter to the study of the "social" requires lopping off a great deal of what most sociologists have always studied: the individual, the psychological, the ideological, the meaning of the human condition, the subjective goals and ends toward which human actions are believed to be directed, and deconstructive and contemplative interpretations of reality. The vast majority of sociologists would no longer be employed in sociology departments - or at least within the proposed sociological framework that has undergone such a radical intellectual liposuction. That may seem cruel and imperialistic. But one does not have to deny the legitimacy of alternative approaches to studying social life, or attempt to dissuade others from pursuing their particular foci in the study of the human condition. Rather a structural realignment would seem to be the solution - and could readily accommodate the pluralism that will almost certainly continue to exist in any event. ${ }^{6}$

\section{Suggestion \#2: Departmental Realignment}

In the early 1990s, in response to departmental debates about alternative sociological approaches, the members of James Madison University's Department of Sociology agreed to recast their course offerings to grant equal recognition to three major intellectual approaches within traditional sociology. Rather than privilege positivism with the generic course offerings of statistics and research methods, the faculty reorganized their sociology major requirements to include three separate theory-methods courses: 1) Critical Analysis; 2) Interpretive Analysis; and 3) Naturalistic (Positivistic) Analysis. The approach helped to diffuse the tensions that existed in that department - tensions that continue to create fundamental fissures, or sometimes prevent departments moving forward with basic hires, in many places in Canada and the United States.

In each of the three sociology departments where I have worked in Canada, for instance, the members have debated vigorously and at times acrimoniously the criteria for hiring new members. A consensus does not exist. While most colleagues will endorse, in principle, the importance of academic publications, teaching evaluations, and departmental needs as key criteria, individual members can - and often do - introduce a great many idiosyncratic, political, or perhaps altogether irrelevant criteria in choosing their short-lists of candidates and ultimately

6. Two decades ago, Collins (1986:1341) wrote of the sociological malaise in the 1980s, noting that "a variety of ... positions prove with philosophical sophistication that only their methods provide any adequate grasp of the social world at all. But the very militancy of these positions, when added to the irremediable structural fact that the sociological world is pluralistic and one's opponents are not going to see the light, must inevitably contribute to the feeling of gloom." 
their voting dispositions (e.g., whether someone has the "right fit" with the department, has an appropriate "social justice orientation," might be considered "friendly" or "good-looking" enough, might be an "American," has a radical or activist agenda, etc.). Excellent candidates may be overlooked or excluded from consideration altogether, often in predictable fashion. ${ }^{7}$

Perhaps the answer lies in creating more departmental diversity rather than a knee-jerk acceptance of disciplinary diversity. Rather than having sociology continue to be the circus with the largest tent in town, an alternative might be to realign departments into theoretically and philosophically coherent entities. Universities may benefit from having more epistemologically cohesive departments of positivist (or "naturalistic") social science, interpretive social science, and critical social science (see Neuman 2006). Such epistemological integration would still countenance theoretical and methodological pluralism, but within shared parameters of knowledge-building that allow for common discourse. What would realigned departments look like?

The positivists would draw mainly upon hypothetico-deductive systems of reasoning, intent upon developing logically interconnected sets of propositions aimed at explaining behavioural regularities, and testable through systematic observation of the measurable aspects of social life (Black 1995; Homans 1967). The interpretive analysts would focus on the symbolic nature of social life, or the importance of understanding the meanings that social actors attach to their behaviours, with a particular focus on direct observations of human beings in their natural environments and their social constructions of reality (Urreiztieta 2004). The critical theorists would be driven explicitly by their value orientations, by particular visions of what constitutes social justice, and by praxis, with the manifest objective of developing ideas that might empower and ideally emancipate individuals and groups to transform their social worlds (Bohman 2002; see Carleheden 1998). Much feminist research might be situated within such departments as well, at least to the extent that practitioners assume a particular value orientation about gender and power relations, as well as incorporate an action-oriented perspective

7. Those who study labour markets and hiring processes can document in much greater detail how these processes work and the nature of the discrimination experienced, but the processes apply just as predictably among "enlightened sociologists" as among the gatekeepers who work in the nefarious corporate world. If a department has predominantly or exclusively "critical sociologists," then how will those who have a scientific orientation compete for jobs (or apply for positions)? Instead, as a recent interviewee mused, "As everyone knows, science doesn't explain anything." Such preaching to the choir will almost certainly earn one a job on the fast-track to sociological success in Canada rather than demonstrating what science can actually accomplish. 
aimed at facilitating personal and societal change (Williams 2006). Lastly, postmodernists would still be able to practice their craft, but logically reintegrated into the arts or humanities from whence they came. The academy still has a place for those who fancy themselves literary and cultural critics, who deconstruct texts, who deny the reality of scientific truth as distinct from personal experience, and who aspire to incorporate themselves into the drama they might wish to share with their audiences but surely from a departmental location distinct from departments of social science (cf. Mirchandani 2005).

\section{Suggestion \#3: Internationalization and Scientific Councils}

John Brauman, a chemistry professor from Stanford and winner of the National Medal of Science, observes that "Science itself is a very international enterprise, and it always has been" (quoted in Altman 2006). The scientific labour force globalized much more rapidly than in other industries, as tens of thousands of students from developing countries studied in Europe and the United States following the Second World War. As these countries developed their own scientific infrastructures and with the diffusion of computers and communication technologies, many students and scholars have enjoyed more opportunities to develop their research and push back the frontiers of knowledge based in their countries of origin. Whatever the critics might claim, the evidence suggests that government and corporate investments have supported the development of a Westernized version of global science for several decades (Drori et al. 2003; Jang 2000; see Schofer 2004). ${ }^{8}$

The social sciences at times have joined such an international community of scientists, but still appear to be much more parochial, especially in sociology, in addressing key questions about social behaviour. Some sociologists continue to trumpet the importance or significance of "national" sociologies, which are often viewed as essential in their linkages with government funding, technical skills development, and policy-relevant responses to extant social problems (e.g., Engbersen 2005; Thorns 2003; Wesolowski 2005; see Crothers 1999; Genov 1989). Another cadre has a more radical agenda, such as championing the development of "non-Western" approaches to social scientific analysis (Reviere 2001; D'Souza 1998). Some are determined to eschew

8. Certain alternatives to mainstream science have developed in various locations across societies. Yet the vast majority of the investments and those committed to developing knowledge and new technologies subscribe to a Western scientific worldview (Schofer 2004). Moreover, while fraud and misrepresentation continue to be serious concerns in the global scientific community, a global workforce of scientists these days tackles the important issues across the scientific landscape. 
scientific sociology altogether in their quest to develop their alternative visions of sociology (Arcaro 1996; Du Bois and Wright 2002). Finally, whatever vision one might have of sociology, Burawoy's (2005) claim that we have entered an era of third-wave sociology and the "end of pure science" sounds remarkably similar to - and about as accurate as - the 1970s Marxists who claimed the imminent demise of capitalism. Sometimes, sociologists are simply wrong.

In contrast, Abbott (2000:298) contends that "internationalization would seem to be the main social structural event in sociology's future." This internationalization can be interpreted quite differently, depending upon one's social science perspective. Appadurai (2000) argues that the internationalization of social scientific research can proceed along one of two lines: 1) "weak internationalization," by which he means the development of a structure or community in which analysts share the vision and imagination of research long recognized as depending upon observation, verification, and replication within a "value-free" context; and 2) "strong internationalization," where scholars from across the globe can debate the nature of research and what constitutes new knowledge - and practitioners consciously reintegrate the moral and political interests of their scholarly research. Many sociologists would surely embrace the latter vision (Blau and Moncada 2007; see Michalski 2005), for the approach implies a type of "globalization from below" in which the new knowledge produced provides a voice for "the poor, the vulnerable, the dispossessed, and the marginalised in the international fora in which global policies are made" (Appardurai 2000:18).

The current paper suggests, however, that the internationalization of sociological research can and should proceed along four distinct lines:

1. a positivist community of scholars organizing their research around studies in observable, behavioural variations;

2. a critical social scientific community committed to knowledgebuilding to politicize the global culture, initiating social change, and empowering the dispossessed to resist their oppressors and reclaim that which rightfully should be shared among peoples everywhere;

3. an interpretive social scientific community committed to understanding the symbolic nature of social life, the meanings that social actors attach, and the processes through which individuals construct their everyday lives; and

4. a postmodernist or humanist community of scholars who approach all forms of knowledge-building and "truth-telling" with scepticism. 
The lines of communications and information flows could be institutionalized and internationalized, should scholarly practitioners and leaders within the academy take seriously the notion of "interdisciplinary" research and reorganize their departments accordingly. International bodies of science may yet have a role to play as well.

There already exist certain international organizations committed to uniting scholars from across the globe, though their purposes can vary. The International Sociological Association (ISA) would be a logical place to start for those who claim to be practising sociologists. The first two articles identified under their statutes appear to offer considerable promise for the global development of sociology. According to Article One, "The ISA is a non-profit association for scientific purposes. Its function is to represent sociologists everywhere, regardless of their school of thought, scientific approaches or ideological opinion" (International Sociological Association 2007). Article Two states that

The goal of the Association is to advance sociological knowledge throughout the world. In its structure, the Association recognizes the aspirations of sociologists in all parts of the world and endeavours to support and strengthen the free development of sociology in cooperation with similar associations of social scientists.

One wonders, though, about the implications that stem from such wording: does the ISA mean to promote and support all forms of knowledgebuilding, an unbounded pluralism of perspectives regardless of the academic or scholarly merits of the work? Surely there must be limits or safeguards as to what constitutes valid sociological knowledge, but their vision of science remains somewhat muddled.

The International Council for Science (ICSU) offers more promise, with more than 100 national scientific bodies and 29 international scientific unions. According to Thomas Rosswall, the Executive Director, the "ICSU is first and foremost a scientific organization and excellence in science underpins everything that we do" (International Council for Science 2006:2). Thus while the ICSU in recent years has stressed possible linkages between the global scientific community and intergovernmental sectors dealing with public policies, basic research continues to be the cornerstone upon which the organization has been built. Although sociology does not receive direct representation in the ICSU, one member that might be scrutinized more closely is psychology, whose model might be especially helpful to draw upon or replicate. The International Union of Psychological Science, founded in 1951, has objectives such as the following: "to develop the exchange of ideas and scientific information among psychologists of different countries and in particular to organize 
international congresses and other meetings on subjects of general or special interest in psychology" and "to engage in other activities that will further the development of the science of psychology."

The International Sociological Association would benefit from the adoption of similar language, particularly in an era where a great many colleagues refuse to either describe their work as "scientific" or even to label themselves "sociologists." Indeed, the extent to which members of sociology departments even have doctoral degrees in sociology might be an interesting measure of disciplinary integration. The lack of collective identity, though, appears to reflect the unmitigated intellectual pluralism of the past several decades that has produced several intellectual enclaves, each with their own journals and "texts." What would global sociology look like from such a vantage point? What intellectual coherence could sociology claim? The best solution might be to simply part ways, as suggested in the current paper, and allow for those inspired by different traditions to pursue their missions in genuine communities of scholars.

\section{Conclusions}

A universalistic "sociology without borders" can be achieved, though not without some serious intellectual realignment. The importance of establishing a disciplinary core cannot be overstated, with the centrality of the "social" serving as the cornerstone of any future conceptualization of our sociological focus. Anyone committed to scientific sociology will appreciate the argument for eliminating those aspects that have hindered the development of a general science of social life. As described in the current paper, scientific sociology can be considered "post-ideological," "post-teleological," and "post-nationalistic." The modernist version invites sociological analysts anywhere and everywhere to examine the full range of cases that reflect purely social behaviour, drawing upon the dimensions of social space or networks of resource flows that are most relevant to their general explanations. Conceptualized this way, sociology becomes a global science no longer handicapped by individualistic theories or nationalistic political fervour. To have a distinct "Canadian" sociology versus an "American" sociology makes no more sense than to claim that "Canadians" and "Americans" are different species of human beings.

Just as important, the models that analysts develop can and should be tested by transcending national boundaries to accumulate comparative and historical evidence, which can be accessed and analyzed more ef- 
ficiently. The theoretical formulations advanced in the current paper, for instance, can be subjected to empirical verification or falsification across the full range of sociocultural contexts. In fact, the most powerful of our sociological theories should meet all of the criteria essential to scientific formulations, i.e., they should be maximally general, parsimonious, testable, valid, and original. Yet the strategies for gathering appropriate data and testing rigorously our most potent sociological theories are still in their infancy. Considerable methodological work remains to be done as a supplement to the theoretical innovation. The available communication technologies will facilitate this theoretical and methodological exchange, while the active engagement of international bodies of science could certainly play a role as well. Tucker (1999) already has recommended that sociologists committed totally to a science of social life should secede from the ASA to establish a new association: the Society for Scientific Sociology.

Whatever their organizational linkages and institutional ties, the current paper advocates that sociologists qua scientists should continue to develop scientific theories and the methodological tools and strategies to test key ideas within contemporary society, as well as cross-culturally and historically. Not all who claim to be sociologists, though, will share in such a vision. A disciplinary realignment will be necessary to facilitate the development of integrated communities of scholars committed to any of the four missions briefly outlined in the emerging global order. Those who subscribe to scientific sociology, though, should be especially optimistic as the scientific community continues to be privileged by having produced the most reliable, valid, and practical knowledge the world has yet known. The failure to embrace scientific sociology will mean that, as Turner (2006:27) laments, sociology will "remain a chaotic discipline, impotent and unable to demonstrate our relevance to understanding the dynamics of the social universe." With any reasonable hope and commitment, excellent scientific sociological analyses will continue to emerge, even in "anti-scientific times" (Massey 2006).

What a life: to search for and possibly discover the sociological laws of the universe, or principles that apply across social space and time. To be able to fully participate in and contribute to a purely scientific conversation about an ontologically distinct "social" life inspires a certain cadre of social scientists to continue the search on even the most dismal days. I can scarcely contain myself when I begin to catch a glimpse of what may lie deep within social space. We are on the verge of some of the most important sociological discoveries in the relatively young history of the social sciences. Scientific sociology continues to afford the discipline an opportunity to transcend the current malaise by moving 
beyond conventional horizons and national borders to establish a global community of sociologists committed to scientific discovery in the fields of law and conflict, as well as the full range of social phenomena that can be conceptualized and studied. As Harold Bloom (2002:4) comments in his introduction to Genius, his discourse on one hundred literary figures: "it is hard to go on living without some hope of encountering the extraordinary." Indeed, recalling a sentiment expressed earlier in the paper about physicists, we might suggest that the social universe has certain key parameters that we are only just now discovering and beginning to understand. For a sociologist, "it's an awesome time to be alive."

\section{REFERENCES}

Abbott, Andrew. 2000. Reflections on the future of sociology. Contemporary Sociology 29(2):296-300.

Alexander, Jeffrey. 1987. The centrality of the classics. Pp. 11-57 in Anthony Giddens and Jonathan H. Turner, eds., Social Theory Today. Cambridge: Polity Press.

Altman, Daniel. 2006. Managing globalization: Science, "A very international enterprise.” International Herald Tribune, September 20.

Amato, Paul R. 1995. Single-parent households as settings for children's development, well-being, and attainment: A social network/resources perspective. Sociological Studies of Children 7:19-47.

American Sociological Association. 2003a. Sociological association takes position on conflict In Iraq. August 1, Press Release, American Sociological Association's website (http://www.asanet.org).

2003b. Minutes of a meeting of the American Sociological Association Council. August 19, American Sociological Association's website (http:// www.asanet.org).

Appadurai, Arjun. 2000. Grassroots globalization and the research imagination. Public Culture 12(1):1-19.

Arcaro, Tom. 1996. What is humanistic sociology, anyway? Humanity and Society 20(2):5-13.

Baumgartner, M.P. 1988. The Moral Order of a Suburb. New York: Oxford University Press.

2002. The behavior of law, or how to sociologize with a hammer. Contemporary Sociology 31(6):644-649.

Best, Joel. 2003. Killing the messenger: The social problems of sociology. Social Problems 50(1):1-13.

Best, Joel and David Schweingruber. 2003. First words: Do sociologists actually use the terms in introductory textbooks' glossaries? The American Sociologist 34(3):97-106. 
Black, Donald. 1976. The Behavior of Law. New York: Academic Press. 1979. A strategy of pure sociology." Pp. 149-168 in Scott G. McNall, ed., Theoretical Perspectives in Sociology. New York: St. Martin's Press. 1989. Sociological Justice. New York: Oxford University Press. 1995. The epistemology of pure sociology. Law and Social Inquiry 20:829-870.

2000a. Dreams of pure sociology. Sociological Theory 18:343-367. 2000b. The purification of sociology. Contemporary Sociology 29:704709 .

2002a. Pure sociology and the geometry of discovery. Contemporary Sociology 31:668-671.

$2002 \mathrm{~b}$. The geometry of law: An interview with Donald Black. Interview by Marcelo Gomes Justo, Helena Singer, and Andreas Bueno Buoro. International Journal of the Sociology of Law 30:101-129. 2004. The geometry of terrorism. Sociological Theory 22(1):14-25.

Blackwell, Judith C., Murray E.G. Smith, and John S. Sorenson. 2003. Culture of Prejudice: Arguments in Critical Social Science. Peterborough, ON: Broadview Press.

Blau, Judith, and Alberto Moncada. 2006. Justice in the United States: Human Rights and the U.S. Constitution. Lanham, MD: Rowman \& Littlefield. 2007. It ought to be a crime: Criminalizing human rights violations. Sociological Forum 22(3):364-371.

Bloom, Harold. 2002. Genius: A Mosaic of One Hundred Exemplary Creative Minds. New York: Warner Books.

Bohman, James. 2002. How to make social science practical: Pragmatism, critical social science and multiperspectival theory. Millennium 31(3):499-524.

Brohm, Jean-Marie. 2004. Critical sociology and critique of sociology. Education et Sociétés 1(13):71-84.

Burawoy, Michael. 2005. Third-wave sociology and the end of pure science. The American Sociologist 36(3/4):152-165.

Camic, Charles (ed.). 1998. Reclaiming the Sociological Classics: The State of the Scholarship. Malden, MA: Blackwell.

Camic, Charles and Neil Gross. 1998. Contemporary developments in sociological theory: Current projects and conditions of possibility. Annual Review of Sociology 24:453-476.

Camic, Charles and Hans Joas (eds.). 2004. The Dialogical Turn: New Roles for Sociology in the Postdisciplinary Age. Lanham, MD: Rowman \& Littlefield.

Carleheden, Mikael. 1998. Another sociology - the future of sociology from a critical theoretical perspective. Dansk Sociologi 9:55-75.

Cole, Stephen (ed.). 2001. What's Wrong with Sociology? New Brunswick, NJ: Transaction. 
Coleman, James. 1990. Foundations of Social Theory. Cambridge, MA: Harvard University Press.

Collins, Randall. 1986. Is 1980s sociology in the doldrums? American Journal of Sociology 91(6): 1336-1355. 1990. The organizational politics of the ASA. American Sociologist 21:311.

Cooney, Mark. 1998. Warriors and Peacemakers: How Third Parties Shape Violence. New York: New York University Press. 2002. Still paying the price of heterodoxy: The Behavior of Law a quarter-century on. Contemporary Sociology 31(6):658-661.

Crothers, Charles. 1999. New Zealand sociology in the new millennium. New Zealand Sociology 14(2):203-219.

D’Souza, Victor S. 1998. Beyond fifty years of India's independence: Challenges to scientific sociology. Sociological Bulletin 47(1):9-15.

Drori, Gili, John W. Meyer, Francisco O. Ramirez and Evan Schofer. 2003. Science in the Modern World Polity: Institutionalization and Globalization. Stanford: Stanford University Press.

Du Bois, William and R. Dean Wright. 2002. What Is humanistic sociology? The American Sociologist 33(4):5-36.

Engbersen, Godfried. 2005. Eternal youth: Continuities and innovations in Dutch sociology. Sociologie 1(1):90-105.

Etzioni, Amitai. 1988. The Moral Dimension: Toward a New Economics. New York: Free Press.

Featherstone, Mike. 2000. Archiving cultures. British Journal of Sociology 51(1):161-184.

Foley, Dennis. 2003. Indigenous epistemology and indigenous standpoint theory. Social Alternatives 22(1):44-52.

Fuller, Steve. 2000. A very qualified success, indeed: The case of Anthony Giddens and British sociology. Canadian Journal of Sociology 25(4):507516.

Genov, Nikolai. (ed.). 1989. National Traditions in Sociology. London: Sage.

Gouldner, Alvin W. 1970. The Coming Crisis of Western Sociology. New York: Oxford University Press.

Halsey, A.H. 2004. A History of Sociology in Britain: Science, Literature, and Society. Oxford: Oxford University Press.

Hiller, Harry. 2001. Legacy for a new millenium: Canadian sociology in the twentieth century as seen through its publications. Canadian Journal of Sociology 26(3):257-263.

Homans, George C. 1967. The Nature of Social Science. San Diego: Harcourt Brace Jovanovich. 
Horowitz, Irving Louis. 1993. The Decomposition of Sociology. New York: Oxford University Press.

Horwitz, Allan V. 2002. Toward a new science of social life: A retrospective examination of The Behavior of Law. Contemporary Sociology 31(6):641-644.

International Council for Science. 2006. Annual Report 2005. Paris: International Council for Science.

International Sociological Association. 2007. Statutes of the International Sociological Association. Available from the website: http://www.isa-sociology.org/about/isa statutes.htm.

Jang, Yong Suk. 2000. The worldwide founding of ministers of science and technology, 1950-1990. Sociological Perspectives 43:247-270.

Lee, Alfred McClung. 1976. Sociology for whom? American Sociological Review 41:925-936.

Lipset, Seymour Martin. 2001. The state of American sociology. Pp. 247-270 in Stephen Cole, ed., What's Wrong with Sociology? New Brunswick, NJ: Transaction.

Lynd, Robert S. 1939. Knowledge for What? The Place of Social Science in American Culture. Princeton, NJ: Princeton University Press.

Lyotard, Jean-Francois. 1992. The Postmodern Explained. Sidney: Power Publications.

Massey, Douglas S. 2006. Doing social science in anti-scientific times. The American Sociologist 37(2):87-95.

Mayhew, Bruce H. 1980. Structuralism versus individualism: Part 1, shadowboxing in the dark. Social Forces 59(2):335-375.

McLaughlin, Neil. 2004. A Canadian rejoinder: Sociology north and south of the border. The American Sociologist 35(1):80-101. 2005. Canada's impossible science: Historical and institutional origins of the coming crisis in Anglo-Canadian sociology. Canadian Journal of Sociology 30(1):1-40.

Michalski, Joseph H. 2003. Financial altruism or universal resource exchanges? Toward a pure sociology of welfare. Sociological Theory 21(4):341358. 2004. Making sociological sense out of trends in intimate partner violence. Violence Against Women 10(6):652-675. 2005. La diversité épistémologique de la sociologie canadienne: Quelques éléments de comparaison entre professeurs Francophones et professeurs Anglophones. Le Cahier de l'ACSALF 2(2):2-3.

Miethe, Terance D. and Wendy C. Regoeczi. 2004. Rethinking Homicide: Exploring the Structure and Process Underlying Deadly Situations. Cambridge: Cambridge University Press. 
Mills, C. Wright. 1959. The Sociological Imagination. New York: Oxford University Press.

Mirchandani, Rekha. 2005. Postmodernism and sociology: From the epistemological to the empirical. Sociological Theory 23(1):86-115.

Morris-Suzuki, Tessa. 2000. Anti-area studies. Communal/Plural 8(1):9-23.

Neuman, William Lawrence. 2006. Social Research Methods: Qualitative and Quantitative Approaches (6 $6^{\text {th }}$ edition). Boston: Allyn and Bacon.

Ogmundson, Richard. 2002. The Canadian case: Cornucopia of neglected research opportunities. The American Sociologist 33(1):55-78.

Phillips, Bernard. 2001. Beyond Sociology's Tower of Babel. New York: Walter de Gruyter.

Reviere, Ruth. 2001. Toward an Afrocentric research methodology. Journal of Black Studies 31(6):709-728.

Sarup, Madan. 1993. An Introductory Guide to Post-Structuralism and Postmodernism. England: Harvester Wheatsheaf.

Schofer, Evan. 2004. Cross-national differences in the expansion of science, 1970-1990. Social Forces 83(1):215-248.

Short, Jr., James F. 2006. Discussion: Wrestling with the beast. Crime, Law, and Social Change 46:87-95.

Simpson, John H. 2005. Comment on 'Canada's impossible science: Historical and institutional origins of the coming crisis in Anglo-Canadian sociology.' Canadian Journal of Sociology 30:113-5.

Smith-Lovin, Lynn. 2000. Simplicity, uncertainty, and the power of generative theories. Contemporary Sociology 29(2):300-306.

Smolin, Lee. 2006. The Trouble with Physics: The Rise of String Theory, the Fall of Science, and What Comes Next. Boston: Houghton Mifflin.

Snow, David A. 1999. 1998 Pacific Sociological Association address: The value of sociology. Sociological Perspectives 42(1):1-22.

Spiro, Melford E. 1996. Postmodernist anthropology, subjectivity, and science: A modernist critique. Society for Comparative Study of Society and History 38(4):759-780.

Thorns, David C. 2003. The challenge of doing sociology in a global world: The case of Aotearoa/New Zealand. Current Sociology 51(6):689-708.

Tucker, James. 1999. Policy advisers and world savers. Contemporary Sociology 28(4):402-403.

Turner, Bryan. 2006. Classical sociology and cosmopolitanism: A critical defence of the social. British Journal of Sociology 57(1):133-151.

Turner, Jonathan. 2003. Face to Face: Toward a Sociological Theory of Interpersonal Behavior. Stanford, CA: Stanford University Press. 
2005. 'Is public sociology such a good idea?' The American Sociologist 36(3/4):27-45.

2006. American sociology in chaos: Differentiation without integration. The American Sociologist 37(2):15-29.

Turner, Stephen P. 1996. Introduction: Social theory and sociology. Pp. 1-16 in Stephen P. Turner, ed., Social Theory and Sociology: The Classics and Beyond. Oxford and Malden, MA: Blackwell.

Urreiztieta, Maria Teresa. 2004. Interpretive sociology: Globalization and daily life. Espacio Abierto 13(3):457-470.

Warde, Alan and Gindo Tampubolon. 2002. Social capital, networks and leisure consumption. The Sociological Review 50:155-180.

Wesolowski, Wlodzimierz. 2005. The opening address: XII Polish Sociological Congress in Poznan. Studia Socjologicne 1:5-9.

Williams, Christine. 2006. Still missing? Comments on the twentieth anniversary of 'The missing feminist revolution in sociology.' Social Problems 53(4):454-458.

Joseph H. Michalski is an associate professor of sociology at King's University College at the University of Western Ontario. His theoretical work and empirical research focus on the geometry of social space in relation to behaviours as diverse as intimate partner violence, altruism, and knowledge production. His efforts these days are mainly committed to the development of a monograph tentatively entitled An Invitation to Pure Sociology, building in part upon his 2008 article, "The Social Life of Pure Sociology," to be published in Sociological Quarterly, Volume 49, Number 2.

jmichal2@uwo.ca 
554 Canadian Journal of Sociology/Cahiers canadiens de sociologie 33(3) 2008 